\title{
Spiritualitas Keugaharian: Perspektif Pastoral
}

(Disajikan pada panel diskusi dalam rangka hari ulang tahun Pendidikan Teologi ke-132 di Ambon, Tahun 2017)

\section{Claartje Pattinama}

Dosen Pastoral dan Psikologi pada Fakultas Teologi UKIM

e-mail: claartjepattinama33@gmail.com

Spiritualias keugaharian adalah cara menghayati dan menjalani kehidupan yang didasari pada etos hidup berkecukupan. Hidup berkecukupan merupakan gaya hidup yang perlu dikembangkan oleh orang-orang percaya atau warga gereja. Hidup berkecukupan dapat dikatakan sebagai hidup yang berlandaskan Alkitab, Matius 6 ayat 11 "berikanlah kami pada hari ini makanan kami yang secukupnya". Dari penggalan doa Bapa Kami ini, saya memahami ungkapan secukupnya tidak hanya berkaitan dengan makanan tetapi menyangkut semua kebutuhan hidup manusia. Hal ini berarti hidup berkecukupan merujuk pada keseimbangan dalam hidup manusia. Keseimbangan dalam kebutuhan hidup manusia menjadi penting, karena keseimbangan dalam kebutuhan hidup dapat menjamin ketentraman. Dengan hidup yang berkecukupan manusia dapat bertahan dalam menghadapi persoalanpersoalan hidupnya, seperti berpikir jernih dan bertindak secara bijak dalam menyelesaikan persoalannya.

Hidup yang berkecukupan tidak sama dengan kemiskinan, karena kemiskinan mengungkapkan tentang hidup yang serba berkekurangan atau ketidakcukupan. Hidup dalam kekurangan membuat manusia merasa tidak bahagia, tidak mengalami sejahtera bahkan tidak berdaya. Kekurangan atau kemiskinan dapat menyebabkan manusia menjadi gelap mata dan dapat memunculkan masalahmasalah sosial, seperti kebodohan, pencurian atau perampokan sampai pada tindakan menghilangkan nyawa orang lain. Tindakan-tindakan seperti ini tidak diharapkan terjadi di kalangan warga jemaat/gereja. Karenanya Gereja sebagai institusi perlu melaksanakan tugas pengutusannya untuk menjaga dan memelihara semua anggota persekutuan atau orang percaya dari kecenderungan tindakan kesewenangan seperti kerakusan dan penumpukkan kuasa, politik, dan ekonomi, baik secara pribadi maupun kelompok, yang mengakibatkan terjadinya kemiskinan bagi manusia lainnya. Kemiskinan yang disebabkan oleh pribadi dan kelompok perlu diselesaikan melalui pendekatan pastoral.

Mereka ini perlu diarahkan untuk melihat orang-orang miskin sebagai saudara yang harus diberdayakan. Kesadaran untuk berbagi dan memberdayakan sesamanya merupakan wujud dari panggilan imannya sebagai orang percaya. Dalam hal ini mereka perlu dilayani agar dapat 
membebaskan diri dari kungkungan kerasukan atau ketamakannya. Seorang yang berada dalam kungkungan ketamakan tidak hanya dilakukan sekali atau dua kali pelayanan pastoral. Ketamakannya akan berkurang jika kesadarannya tumbuh karena pelayanan pastoral yang dilakukan dengan kasih dan keseriusan, disertai doa terus-menerus, serta mencari kebenaran hidup melalui pembacaan Alkitab. Ketamakan dapat hilang jika dirinya disentuh cinta-kasih melalui pelayanan pastoral, serta didorong untuk merasa solider dengan orang-orang yang dikorbankannya. Dengan kata lain pertobatan yang sungguh muncul bukan semata-mata dari kesadaran diri sendiri, tetapi ia ditolong, diterima, didengarkan dan mendengarkan pelayan serta ditopang dengan doa-doa yang terus-menerus dari pelayan(pendeta) untuk membebaskan dirinya dari kungkungan yang menyengsarakan orang lain. Janganlah pelayan mempersalahkan, menyudutkan dan menempatkan diri orang seperti ini sebagai pendosa yang kejam dan tidak memiliki kesempatan untuk menemukan jalan kembali.

Gereja diutus kedalam dunia untuk bersaksi tentang kehendak Tuhan dalam realitas kehidupan mereka, dan Gereja ditugaskan untuk menjaga dan melindungi kehidupan manusia agar dapat mengalami hidup yang berkecukupan sebagaimana yang terungkap dalam penggalan doa Bapa Kami(Mat. 6 : 11). Berkaitan dengan tugas pengutusan ini maka Gereja perlu melaksanakannya baik dalam bentuk pemberitaan, pendidikan dan pelayanan pastoral. Pelayanan pastoral sebagai salah satu bentuk pelayanan pribadi maupun persekutuan dalam rangka menolong warga gereja atau jemaat berhadapan dengan persoalan hidupnya. Kesungguhan pelayan (pendeta) dalam pelayanannya perlu diperlihatkan melalui kesetiaannya melaksanakan pelayanan pastoral sebagai utusan Tuhan Yesus Kristus Pastor yang Agung.

Dalam hubungan itu, Gereja sebagai persekutuan orang percaya perlu mengembangkan spiritualitas keugaharian. Dalam pengertian setiap anggota gereja mesti menghayati dan mempraktekkan gaya hidup yang berkecukupan. Jika ada anggota yang berkelebihan atau berkelimpahan ada baiknya ia dilayani agar dapat mempraktekkan dan mengembangkan gaya hidup berbagi dengan anggota lain dalam persekutuan maupun orang di luar persekutuan. Dengan demikian kelebihan atau kelimpahannya mencukupkan kebutuhan orang lain. Gaya hidup keugaharian tidak akan terjadi dengan sendirinya di kalangan warga gereja. Gereja dalam pelayanannya baik melalui pemberitaan firman, pendidikan formal maupun non formal gereja dan pelayanan pastoral perlu menegaskan tentang gaya hidup berkecukupan ini. Jika penghayatan hidup berkecukupan dipraktekkan dengan benar oleh semua warga gereja, maka dapat dikatakan bahwa persekutuan gereja menjadi “komunitas moral yang dapat mempengaruhi gaya hidup masyarakat. 
Gaya hidup berkecukupan bukan saja diberitakan dan dianjurkan pelayan gereja (pendeta), tetapi pendetalah yang pertama-tama harus menjadi model atau contoh dari gaya hidup berkecukupan itu. Terkait dengan itu juga diharapkan program-program pelayanan yang diputuskan atau dirumuskan dalam setiap persidangan di berbagai tingkatan (Sinode, Klasis dan Jemaat) tidak harus mempertontonkan kelebihan atau kemewahan yang memunculkan persungutan di kalangan warga gereja. Kalau hal seperti ini terjadi berarti, para pelayan gereja (pendeta), majelis jemaat dan pengurus atau pelayan lainnya belum memahami dan menginsyafi secara benar spiritualitas keugaharian yang diberitakan, serta tidak menciptakan keseimbangan dalam kehidupan bergereja atau berjemaat. Semestinya program-program pelayanan yang diputuskan dalam persidangan gereja atau persidangan tidak harus menimbulkan persungutan. Adalah lebih baik jika program-program pelayanan tersebut lebih menitik beratkan keseimbangan dan pemberdayaan bagi warganya.

Rasul Paulus dalam Filipi 4 ayat 11 b menyatakan "sebab aku telah belajar mencukupkan diri dalam segala keadaan" nas ini hendak menunjukkan bahwa sebagai pelayan jemaat, ia memahami benar gaya hidup yang harus dipraktekkan dan perlihatkan kepada warga jemaat, bahwa dalam pelayanannya ia tidak menuntut atau menekan warga jemaat untuk memenuhi kebutuhan hidupnya secara berkelebihan. Yang penting baginya adalah melaksanakan tugas pelayanan sebagaimana mestinya. Disini Rasul Paulus melaksanakan tugas pelayanannya, bukan berdasar kehendak dan kewibawaannya, tetapi ia melakukannya sebagai utusan dan pelayan Yesus Kristus. Jadi para pelayan (pendeta) patut menjadikan Rasul Paulus sebagai contoh pelayan yang lebih mengutamakan pelayanannya kepada jemaat, sebagai utusan Yesus Kristus.

Seperti telah dikatakan bahwa jika gereja sebagai persekutuan dapat menjadikan dirinya sebagai komunitas moral dalam mengembangkan gaya hidup berkecukupan, maka hal itu akan berdampak atau berpengaruh terhadap gaya hidup masyarakat umumnya. Hal ini memang tidak mudah, karena membutuhkan kesungguhan para pelayan (pendeta) terus-menerus mengembangkan pelayanan yang menyentuh kesadaran warga jemaat untuk membiasakan diri dengan gaya hidup yang berkecukupan serta seimbang, sehingga tidak mengorbankan anggota keluarga lainnya. Dikatakan demikian, karena adanya tradisi atau kebiasaan yang selalu dipraktekkan terus-menerus, yakni tradisi berpesta, atau merayakan suatu peristiwa atau tahapan hidup seseorang dengan mengeluarkan banyak beaya. Contoh ketika seorang anak di baptis, pengakuan iman pribadi (sidi) peristiwa-peristiwa ini selalu dirayakan dengan mengeluarkan beaya yang tidak sedikit. Sebagian orang beralasan bahwa hal itu merupakan bentuk pengucapan syukur. Sah-sah saja kalau bentuk pengucapan syukur itu tidak mengeluarkan 
banyak beaya, tidak mengorbankan kebutuhan yang lain, atau tidak menggadai barang berharga, menjual sebidang tanah, atau meminjam uang dari orang. Kalau yang demikian terjadi sangat disayangkan, karena pengucapan syukur itu cuma kesenangan atau kegembiraan sesaat, selanjutnya mengakibatkan beban yang harus dipikul. Ada mahasiswa yang terpaksa harus cuti kuliah karena orangtuanya tidak lagi memiliki uang disebabkan pesta bagi saudaranya baru saja menikah dan perayaan sidi bagi saudaranya yang lain. Seharusnya setiap warga jemaat memiliki prioritas dalam pengelolaan keuangannya. Dengan kata lain pemahaman dan penghayatan serta pemberlakuan gaya hidup berkecukupan mestinya dipraktekkan, sehingga tidak menimbulkan ketidakseimbangan dalam hidup keluarga.

Gaya hidup berpesta yang memunculkan ketidakseimbangan dalam memenuhi kebutuhan hidup anggota keluarga lain, merupakan tantangan dalam pelayanan gereja. Para pelayan (pendeta) dan majelis jemaat setiap saat perlu menyadarkan warga gereja melalui pelayanan pastoral keluarga agar tradisi berpesta perlu dikurangi. Tidak harus setiap fase dan peristiwa dalam kehidupan warga jemaat dirayakan dengan pesta yang berlebihan. Untuk memperkuat pelayanan pastoral dalam rangka mempraktekkan hidup berkecukupan, maka para pelayan perlu menjadi model atau contoh untuk mempraktekkan gaya hidup berkecukupan tersebut, yakni kebiasaan berpesta yang menghabiskan banyak dana tidak lagi dilakukannya. Sehingga pelayanan pastoral yang dilakukan berimbas pada pembentukan perilaku hidup warga jemaat yang tidak boros. Para pelayan tidak perlu mempertahankan gengsinya dengan gaya hidup yang boros. Jika para pelayan tidak mempraktekkan gaya hidup berkecukupan, pasti akan menjauhkan warga jemaat dari gaya hidup yang berkecukupan. Dengan kata lain hidup warga jemaat bisa jadi jadi makin terpuruk dalam gaya hidup boros yang memiskinkan. Padahal yang diharapkan adalah kehidupan warga jemaat mestinya menjadi "komunitas moral" yang mempraktekkan hidup yang berkecukupan akan mempengaruhi kehidupan masyarakat umumnya.

Gereja tidak dapat berjuang atau bekerja sendiri untuk menghapuskan kemiskinan dan penderitaan yang terjadi dalam masyarakat. Karenanya, gereja perlu menyuarakan suara kenabiannya dalam rangka mengkritisi praktek-praktek yang menyebabkan kemiskinan. Gereja perlu bekerja sama dengan agama-agama lain untuk memperjuangkan hak-hak hidup masyarakat. Hanya dengan demikian perjuangan gereja bermakna bagi kemaslahatan bersama dalam masyarakat dan bangsa Indonesia. 